\title{
The Efficient Use of Group Averages as Nondiscrimination: A Rejoinder to Professor Benston*
}

\author{
Lea Brilmayer, $\dagger$ Douglas Laycock, $\dagger \dagger$ and Teresa A. Sullivan $\dagger_{\dagger} \dagger$
}

Professor Benston attacks ${ }^{2}$ our defense ${ }^{2}$ of the principle of City of Los Angeles v. Manhart, ${ }^{3}$ that employers must use sexually integrated actuarial tables in employer-sponsored insurance plans. ${ }^{4}$ Despite the imposing bulk of his essay, Benston contributes little new evidence to the debate. He explicitly assumes his legal conclu-

* The authors acknowledge the helpful comments of Ingrid Waldron and the research assistance of Richard G. Rogers. In accord with scientific custom, the authors' names are in alphabetical order to indicate equal responsibility.

$\dagger$ Professor of Law, Yale University.

t† Professor of Law, The University of Texas at Austin.

tit Associate Professor of Sociology and Faculty Research Associate in the Population Research Center, The University of Texas at Austin.

${ }^{2}$ Benston, The Economics of Gender Discrimination in Employee Fringe Benefits: Manhart Revisited, 49 U. CHr. L. REv. 489 (1982).

' Brilmayer, Hekeler, Laycock \& Sullivan, Sex Discrimination in Employer-Sponsored Insurance Plans: A Legal and Demographic Analysis, 47 U. CHr. L. Rev. 505 (1980).

435 U.S. 702 (1978).

- Id. at 707-11. Most courts continue to reject insurance industry efforts to limit the application of Manhart. See Spirt v. Teachers Ins. \& Annuity Ass'n, 691 F.2d 1054 (2d Cir. 1982) (holding Manhart applicable to employee pension plans administered by third party insurers), petition for cert. filed, 51 U.S.L.W. 3394 (U.S. Nov. 9, 1982) (No. 82-791); Norris v. Arizona Governing Comm. for Tax Deferred Annuity \& Deferred Compensation Plans, 671 F.2d 330 (9th Cir.) (holding Manhart applicable to a deferred compensation plan that gave employees a choice of several insurers), cert. granted, $103 \mathrm{~S}$. Ct. 205 (1982). The courts, however, are no longer unanimous. See Peters v. Wayne State Univ., 691 F.2d 235 (6th Cir. 1982), petition for cert. filed, 51 U.S.L.W. 3394 (U.S. Nov. 10, 1982) (No. 82-794). The Peters court found Manhart wrong in principle, 691 F.2d at 239-40, and distinguished it on two grounds: Wayne State pays women smaller periodic benefits for the same contributions, whereas the employer in Manhart had charged women larger contributions for the same periodic benefits, $i d$. at 240 , and Wayne State hires an insurer to administer its annuity plan, whereas the employer in Manhart had administered its own, id. The first distinction is plainly fallacious. The second ignores the fact that Wayne State offered the discriminatory annuity plan to its employees as compensation for their labor; who does the paperwork and manages the fund is irrelevant.

The Justice Department has filed a brief in Spirt urging the Court to grant the petition for certiorari, but endorsing the plaintiff's basic position that the statute requires that annuity benefits be calculated without regard to sex. Brief for EEOC as Respondent, and for the United States as Amicus Curiae in support of Respondent at 10-13, Spirt v. Teachers Ins. \& Annuity Ass'n, 691 F.2d 1054 (2d Cir.), petition for cert. filed, 51 U.S.L.W. 3394 (U.S. Nov. 9, 1982) (No. 82-791). 
sion $^{5}$ and begs other fundamental questions in equally obvious ways. ${ }^{6}$ His lengthy discourse on the characteristics of insurance differs only slightly from Professor Kimball's earlier explanation. ${ }^{7} \mathrm{His}$ demographic evidence is fully consistent with the evidence and arguments we presented, ${ }^{8}$ despite his contrary assertions. ${ }^{9}$

What is new in Benston's approach is the explicitness and scope of his definition of nondiscrimination. He has melded the unrelated policies of group equality and efficiency, which constituted the bases for earlier attacks on Manhart, ${ }^{10}$ and has carried the combination to its logical extreme. Incredibly, his response states that sex and race discrimination are no different from any other kind of discrimination. ${ }^{11} \mathrm{He}$ believes that nondiscrimination requires that average group differences be taken into account whenever it is efficient to do so, ${ }^{12}$ but he offers no legal analysis to support this startling reinterpretation of federal law. Nothing in his article casts doubt upon our original conclusions.

\section{Benston's Vision of Fairness}

Benston's vision of fairness, one that probably accounts for much of the hostility to Manhart, runs roughly as follows. Compare a man and a womàn retiring at age sixty-five with equal total pension contributions over the course of their careers. If the average number of additional years beyond age sixty-five that previous women have lived is eighteen, but the average additional years that men have lived is fourteen, it is unfair to pay these two individuals the same periodic benefits. ${ }^{13}$ All other things being equal, we

- Benston, supra note 1, at 493.

- See id. at 506 n.43, 507 (asserting without analysis that life expectancy based on group average is an individual trait); id. at $511 \mathrm{n} .61$ (confusing argument that sex is often an efficient predictor with unrelated argument that many employers may prefer to discriminate).

${ }^{7}$ Compare id. at 494-505 with Kimball, Reverse Sex Discrimination: Manhart, 1979 Am. B. Found. Research J. 83, 97-103.

Compare Benston, supra note 1, at 512-29 with Brilmayer, Hekeler, Laycock \& Sullivan, supra note 2, at 539-59. For additional demographic data, see infra notes 97-161 and accompanying text.

- Benston, supra note 1 , at 492, 512-13.

10 See Kimball, supra note 7, at 103-23; Rutherglen, Sexual Equality in Fringe Benefit Plans, 65 VA. L. REv. 199, 205-16, 248-55 (1979).

11 See Benston, Discrimination and Economic Efficiency in Employee Fringe Benefits: A Clarification of Issues and Response to Professors Brilmayer, Laycock, and Sullivan, 50 U. ChI. L. Rev. 250, 254, 257, 263 (1983).

${ }^{12} I d$. at 251 n.7, $273,278$.

13 This four year differential approximates data for the United States for years between 1969 and 1979. See infra Table B. 
should expect the woman to live four years longer than the man, and we should calculate her disbursements on the assumption that her fund will have to last that much longer. She should have no complaint, even if she were to die the very next day, because she will have obtained an equal expected value at the beginning. Professor Kimball has added that many men would gladly trade places with women and give up higher periodic annuity payments in exchange for the chance of living longer. ${ }^{14}$ The free market is said to guarantee this equal expected value, ${ }^{18}$ and if annuities are priced to reflect the best prediction of life expectancy that is administratively feasible, the purchaser's subjective expectation of value is said to equal or exceed the price paid. ${ }^{16}$

By viewing fairness in this way, Benston fundamentally misconceives the basic principles of civil rights law. He also makes one of two elementary errors of logic: either he confuses causation with correlation, or he misunderstands the significance of noncausal correlation. We consider the logical error first, and the legal principles second.

\section{A. Correlation and the Causes of Mortality}

The mischief caused by confusing causation with correlation is illustrated by a famous study of sex discrimination in admission to Berkeley graduate programs. ${ }^{17}$ Men had a much higher admission rate than women. One tends, as the authors noted, ${ }^{18}$ to jump to the conclusion that some sort of discrimination was afoot, that "all other things being equal," a man had a higher chance of being admitted because of his gender. In fact, no such discrimination existed. Instead, women tended to apply to departments with low admission rates. ${ }^{18}$ The chances of success for men and women were identical once all other things were in fact made equal by controlling for the truly causative factor, the department to which the application was directed. Whatever advantages there might have been in being male, they did not ensure a spot in graduate school.

This phenomenon, sometimes referred to as Newcomb's paradox, ${ }^{20}$ can arise whenever statistical predictions are made, includ-

14 Kimball, supra note 7, at 123.

16 Benston, supra note 1 , at 529-32.

16 Id. at 496-505.

17 Bickel, Hammel \& O'Connell, Sex Bias in Graduate Admissions: Data From Berkeley, 187 ScIENCE 398 (1975).

18 Id. at 398-99.

19 Id. at 399.

${ }^{20}$ For a general discussion of Newcomb's paradox, see B. Skyrms, Causar Necrssity 
ing predictions made in the calculation of insurance benefits. Assume, for example, that self-destructive behavior causes higher mortality after age sixty-five, with the hypothetical results shown in Table A. ${ }^{21}$

TABLE A

Hypothetical Longevity After Age 65, By Sex and Behavior Pattern

\begin{tabular}{lll}
\hline \hline & Men & Women \\
\hline $\begin{array}{l}\text { Self-destructors } \\
\text { (e.g., smokers, heavy } \\
\text { drinkers, Type A } \\
\text { personalities) }\end{array}$ & $\begin{array}{l}300 \text { cases } \\
\text { living } 10 \text { years } \\
\text { on average }\end{array}$ & $\begin{array}{l}100 \text { cases } \\
\text { living } 10 \text { years } \\
\text { on average }\end{array}$ \\
\hline $\begin{array}{l}\text { Non-self-destructors } \\
\text { Total }\end{array}$ & $\begin{array}{l}200 \text { cases } \\
\text { living } 20 \text { years } \\
\text { on average }\end{array}$ & $\begin{array}{l}400 \text { cases } \\
\text { living } 20 \text { years } \\
\text { on average }\end{array}$ \\
\hline & $\begin{array}{l}500 \text { men } \\
\text { living 14 years } \\
\text { on average }\end{array}$ & $\begin{array}{l}500 \text { women } \\
\text { living 18 years } \\
\text { on average }\end{array}$ \\
\hline
\end{tabular}

If we were to look only at the bottom row of Table A, all we would see is that a woman's life expectancy appears longer than a man's. It would be tempting to assume the existence of a connection between sex and life expectancy that will cause a man to live four fewer years than a similarly situated woman. Benston makes exactly this mistake, moving from statements about average mortality differences to assertions that, "all other things being equal," a woman should live longer than a man. ${ }^{22}$ But as the two top rows of the hypothetical table illustrate, male and female life expectancy may be equal even with segregated tables when all other things are equal.

128-32 (1980); E. Eells, Newcomb's Paradox and the Principle of Maximizing Conditional Expected Utility (Nov. 1979) (unpublished manuscript on file with The University of Chicago Law Review). For criticisms of the use of correlation-based prediction schemes that lack plausible causal support, see Underwood, Law and the Crystal Ball: Predicting Behavior with Statistical Inference and Individualized Judgment, 88 YALE L.J. 1408, 1444-47 (1979).

21 These are fictitious data, chosen solely for arithmetic simplicity to clarify the conceptual issues. They simplify only slightly, however, what we know about the causes of sex mortality differentials ("SMDs"), because self-destructive behavior by men explains much of the SMD in the United States. Brilmayer, Hekeler, Laycock \& Sullivan, supra note 2, at 552-53.

22 Benston, supra note 1 , at 506, 509. His arguments about the causes of SMDs come much later, see id. at 519-25, and do not support his claims about what would happen if all other things were equal, see infra notes $90-92$ and accompanying text. 
Manhart's critics argue that it is impractical to take account of factors other than gender; ${ }^{23}$ they claim that self-destructive behavior, though known to affect life expectancy, is an inefficient predictor because it is expensive to monitor. ${ }^{24}$ We have no reason to question these claims, because even if true they say nothing about the choice between the remaining alternatives. Those alternatives are either to use sex as the sole predictor or to pool all available data without differentiation as to sex or behavior. ${ }^{25}$ Benston argues that it is unfair and, in fact, illegal to use aggregate data rather than sex-distinct mortality tables. ${ }^{26}$

It is hard to understand why the use of merged-gender mortality tables is unfair to men. It has a disparate impact ${ }^{27}$ on men as a group $^{28}$ because it disadvantages self-destructors, and more men than women are self-destructors. ${ }^{29}$ The total annuity payout to the 500 hypothetical men in Table A would be less than the total amount paid to the 500 women because the total number of years the men would live would be less. ${ }^{30}$ But are men, especially nonself-destructors, entitled to cash in on the fact that many of their sex self-destruct, and is this "entitlement" one that rises to the level of a right protected by Title VII? ${ }^{31}$ There is no merit in Ben-

2s See, e.g., Benston, supra note 1, at 517-19, 530-31; Kimball, supra note 7, at 119-20. Smoking, however, is often considered in the calculation of life insurance premiums. Fair Insurance Practices Act: Hearings on S. 2204 Before the Senate Comm. on Commerce, Science and Transportation, 97th Cong., 2d Sess. 132-33 (1982) (statement of Barbara J. Lautzenheiser, on behalf of the American Council of Life Insurance); Brilmayer, Hekeler, Laycock \& Sullivan, supra note 2, at 533 n.130.

3t See Benston, supra note 1, at 517-19; Kimball, supra note 7, at 119-20.

${ }^{3}$ When sex is used as a predictor, male life expectancy is lower and annual annuity payments are higher than those for females; when the data are pooled, male and female expectancies and payments are the same. See Brilmayer, Hekeler, Laycock \& Sullivan, supra note 2, at 511-14; infra notes $34-40$ and accompanying text.

${ }^{36}$ Benston, supra note 1, at 505-06, 508-11, 512, 525, 542.

57 Civil rights law has distinguished sharply disparate treatment from disparate impact. An employer engages in disparate treatment when he deliberately treats a woman and a man differently because of their sex; he causes a disparate impact when he treats his employees in a way that is facially neutral with respect to race and sex, but that adversely affects a larger proportion of one race or sex than the other. See International Bhd. of Teamsters v. United States, 431 U.S. 324, 335 n.15 (1977); Brilmayer, Hekeler, Laycock \& Sullivan, supra note 2, at 508-11.

28 Brilmayer, Hekeler, Laycock \& Sullivan, supra note 2, at 510-11.

29 Id. at 552-53.

so Using the hypothetical data from the last line of Table $A$ and assuming retirement at age 65 , the expected number of payment years for the 500 men would be 7000 , compared to 9000 for the women.

s1 Civil Rights Act of 1964, Title VII, 42 U.S.C. $§ \S 2000$ e to 2000 e-17 (1976 \& Supp. V 1981). For a discussion of Title VII policy and the choice between disparate treatment and disparate impact in the area of pension benefits, see infra notes 56-61 and accompanying text. 
ston's sweeping claim that men are discriminated against whenever sex is an efficient predictor but is not used..$^{32}$

When sex is used to calculate pension contributions or benefits, the woman's complaint is clear. It is false to claim, as Benston does, ${ }^{33}$ that a woman receives subjective value equal to that which a man receives. She knows subjectively that an identically situated man has an equal life expectancy but gets higher periodic benefits. The reason may be that the insurance company lacks inexpensive access to accurate information concerning its annuitants' habits, but her understanding of the company's perspective does not increase her subjective valuation of the periodic benefits.

Benston would assure the woman that it is fair to treat her as the average woman because her benefits are based on "her" individual life expectancy. He asserts that life expectancy is an individual characteristic ${ }^{34}$ and that the value of any particular annuity to a woman is greater than its value to a similarly situated man..$^{35}$ This argument was raised originally by Professor Kimball, ${ }^{38}$ refuted in some detail by us, ${ }^{37}$ and largely conceded in Kimball's reply. ${ }^{38}$ Ignoring the substantial prior development of this issue, Benston simply asserts that life expectancy is "a characteristic shared by every individual woman," "39 without a word of analysis to support his conclusion. Yet as we have shown, statisticians deny the possibility of "true" individual expectancies."

32 Benston repeats this assertion at numerous points in his article. See Benston, supra note 1 , at 505-06, 508-11, 512, 525, 542 .

ss See id. at 502-03, 505-06. The "subjective value" argument is fallacious even apart from a Title VII context. For example, a terminally ill insured, male or female, will not get true subjective value from an annuity that does not take illness into account in calculating benefits. Neither the insurance company's own prediction of expectancy nor other insurance companies' unwillingness to offer better rates will influence the purchaser's subjective value. Further, no inference about subjective value can be drawn from the fact of purchase when the purchase is involuntary, as is often the case in an employment context. But Benston's subjective value argument at least avoids Kimball's error of assuming that the value to the employee always equals the cost to the employer. Compare Kimball, supra note 7, at 100-01 with Brilmayer, Hekeler, Laycock \& Sullivan, supra note 2, at $518 \mathrm{n} .54$ and Benston, supra note 1 , at 504 .

st Benston, supra note 1 , at $506 \mathrm{n.43,} 507$.

ss Id. at 497-98.

36 Kimball, supra note 7, at 101-02.

37 Brilmayer, Hekeler, Laycock \& Sullivan, supra note 2, at 511-14.

ss Kimball, Reprise on Manhart, 1980 Am. B. Found. Rusearch J. 915, 917 (life expectancy is "a matter of averages, not an individual characteristic").

30 Benston, supra note 1, at $506 \mathrm{n} .43$; see also id. at 507 .

10 See Brilmayer, Hekeler, Laycock \& Sullivan, supra note 2, at 512-13. Measuring an individual's life expectancy is not like measuring his height. It is a prediction based on the past experience of a group, and it presupposes a decision about how individuals should be grouped. 
Benston could offer the same correlation-based justification of individual expectancy to a woman refused credit on the ground that women have been poor credit risks in the past. Her "own" arithmetically calculated credit rating that took sex into account would injure her ability to compete in the credit market. ${ }^{41}$ Similarly, one could deny parole to a black while granting the parole request of a similarly situated white, so long as it could be shown that recidivism correlates with race..$^{42}$ College admissions officials could use ethnicity as a factor to predict the grade-point averages of applicants, if in fact the two were shown to be correlated. In the cases posited, sex, race, and ethnicity would be "efficient" predictors because they are inexpensive selection criteria to administer. In addition, each person would be given the benefit of his or her true "individual expectancy" in exactly the same sense that Benston asserts annuitants are given the benefit of their "individual" expectancies. That is, each person would be treated as the average member of his or her racial, sexual, or ethnic group..$^{43}$

Benston's obvious response is to say that sex itself is the primary cause of the sex mortality differential ("SMD"), 44 but even his data do not support that conclusion. More important, he cannot rely on claims of a causal connection between life expectancy and gender because ultimately his argument depends on efficiency considerations rather than on causation. He repeatedly states that efficient predictors, not causally related predictors, must be used, ${ }^{45}$ and he finds it unnecessary for insurance predictions to be

11 Fortunately, the Equal Credit Opportunity Act, 15 U.S.C. $\$ 1691(a)(1)$ (1976), prohibits such discrimination.

42 In response to these hypothetical situations, Benston concedes that paramount social concerns sometimes may override the use of efficient predictors. See Benston, supra note 11, at 259 n.30. We would argue that sexual equality is a paramount social concern.

4s Any time that group statistics are calculated on the basis of gender, they can be rephrased as "individual characteristics that are the same for all members of a given gender." Benston, supra note 1, at 507. We make an "individual" prediction whenever we attribute a group stereotype to an individual. To attribute to Sally Smith, on the basis of her sex, an inability to supervise male subordinates or a predisposition to quit work and have children is to make an individual prediction about Smith, a prediction that is "the same for all members of a given gender." It is nonetheless invidious and is no different from the predictions made for annuities in sex-distinct mortality tables or the examples posited in text.

44 Benston, supra note 1, at 519-25; see also Benston, supra note 11, at 271. He seems to concede that he has the burden of proof on this issue. Benston, supra note 1, at 493 ("I accept the burden of showing that insurers' use of sex-distinct mortality tables for calculating the benefits from annuities and life insurance is necessary to avoid unfair treatment of people with respect to their gender.").

45 See, e.g., Benston, supra note 1, at 505-06, 508-13, 524, 542. In the introduction to his analysis of the demographic data, he says, "[t]he essential question that must be consid- 
grounded in theory. ${ }^{46}$ In his response, he agrees with us that the issue of a biological or genetic advantage is legally irrelevant. ${ }^{47}$

Because Benston is interested only in efficiency, he concludes that an unregulated insurance market will reach the "fair" result. ${ }^{48}$ To the extent that the market works, it pressures insurers into using the most efficient predictor regardless of whether there is a causal connection between predictor and risk predicted. ${ }^{49}$ An insurer would like to offer lower rates to self-destructors in order to capture that segment of the annuity market, but Benston observes that the administrative costs of gathering information and monitoring insureds are prohibitive. ${ }^{50}$ Sex, however, is an efficient predictor, at least in the short run, ${ }^{11}$ because it can be considered inexpensively. By offering males lower rates, insurers can maximize sales to self-destructors. ${ }^{22}$ The insurer is willing to pay an unavoidable windfall to non-self-destructive men, and the disadvantage to self-destructing women (of higher rates) is relevant to the insurer only if some other company can lure their business away. But it is equally expensive for other insurers to base their rates on factors such as self-destructive behavior. The market pressures all insurers to use sex, not because it is relevant in and of itself, but because it is the cheapest predictive variable available.

The same market forces might pressure an employer into using race, sex, or religion in other types of employment decisions, merely because these factors are cheap to administer and are correlated with characteristics the employer wishes to predict. For example, an employer wishing to avoid employees who abuse drugs

ered now is whether the data on gender-related life expectancy qualify as efficient estimators of the risk of death." Id. at 513 (emphasis added).

" "It is preferable that the postulated relationship be grounded in a theory that efficiently predicts the effect of changed circumstances on life expectancy. But this is not necessary if past relationships have been stable and previous predictions accurate." Id. at 514 .

47 Benston, supra note 11, at 267.

- Benston, supra note 1, at 498, 529-32.

6) We adhere to our view that insurance markets do not foster competition to the benefit of consumers, especially with respect to employer-sponsored plans. Brilmayer, Hekeler, Laycock \& Sullivan, supra note 2, at 531 n.125. In the employment context, deviation from perfect competition results when insurance products are group-purchased by the employers instead of by the ultimate consumers, the employees; this sort of deviation has tended to aggravate sex discrimination, rather than to ameliorate it. Id. For example, employers continue to charge women more than they charge men for annuities, but as much as they charge men for life insurance. Id. at 529-30.

so Benston, supra note 1 , at 500-01.

s1 The instability of SMDs casts serious doubt on the efficiency of sex as a predictor in the long run. See infra notes 119-54 and accompanying text.

s2 See supra note 29 and accompanying text. 
might refuse to hire blacks altogether. He could claim plausibly that race is an efficient predictor, on the grounds that whites have a lower probability of drug abuse, and that regular testing of employees is expensive. The weakness of Benston's argument that the greater life expectancy of females is an individual trait of a woman employee $^{53}$ becomes readily apparent in this context. Correlation between drug abuse and race could equally be said to make predicted drug usage an individual trait for any black applicant. Under Benston's vision of fairness, it would be unfair to white job applicants if the employer did not maximize the number of drugfree employees by hiring only whites. Benston is not arguing merely that Title VII should permit employers to use efficient predictors; he is arguing that Title VII requires their use. A white applicant, even a white drug addict, would have a claim of racial discrimination against an employer who hired blacks. ${ }^{54}$ In Benston's view, the most efficient predictor must be taken into account. $^{.55}$

\section{B. The Requirements of the Civil Rights Statutes}

Benston makes little effort to reconcile his view of fairness with civil rights law, and his insistence that all efficient predictors must be used has consequences that are wildly inconsistent with the statutes. ${ }^{56}$ The claim that Congress wished only to prohibit em-

ss See Benston, supra note 1, at 506 n.43, 507.

s. The white drug addict would be like the physically fit, nonsmoking male in the annuity context. Both claim the advantage of group characteristics inapplicable to themselves. If race were used to predict drug abuse, all white applicants would have a higher expected value to the employer than black applicants, and it would be discrimination to hire the "less qualified" blacks.

${ }^{85}$ See Benston, supra note 1 , at 505-06, 508-12, 525, 542. Benston states that fringe benefit calculations are very different from hiring decisions, $i d$. at 495,510 , but he offers no reason for this distinction. He also concedes that " "even when sex is strongly associated with a job qualification, at least some members of both sexes are qualified," id. at 510 (quoting Brilmayer, Hekeler, Laycock \& Sullivan, supra note 2, at 527), but he says that this point "is irrelevant to insurance," $i d$. The point is not irrelevant, however, because even if sex and mortality were strongly associated, sex-segregated life expectancies would be inaccurate for many individuals of both sexes. Hiring decisions also are based on expectancies about an applicant's value to an employer, and these also will be inaccurate in individual cases. Thus, Benston cannot hide the absurdity of equating efficiency with nondiscrimination by arbitrarily exempting hiring decisions from his definition.

Bo See Equal Pay Act of 1963, 29 U.S.C. \$ 206(d) (1976); Civil Rights Act of 1964, Title VII, 42 U.S.C. $\$ \S 2000$ e to 2000 e-17 (1976 \& Supp. V 1981). In his argument that the use of efficient predictors is required, Benston implies what he now states explicitly in his response: he considers sex and race indistinguishable from any other predictive variables. Benston, supra note 11, at $250,254,258,263$. He concedes only that employers historically have used sex and race as predictors because of bigotry rather than efficiency, and that this 
ployment decisions that market forces would rule out even in the absence of the statutes is simply implausible:"s7 "efficient" discrimination is widespread, and some economists believe that the primary cause of discrimination is the desire to use race and sex as cheap proxies for traits with which they are correlated. ${ }^{.8} \mathrm{An}$ "efficiency exception" would create a massive loophole in the statute and in civil rights policy generally. It also would be unfair to persons who are denied individual consideration in employment decisions, and it is that unfairness to individuals that lies at the core of civil rights policy.

Benston's definition of nondiscrimination is actually a variation on one of the two competing models of equality. Paying a woman periodic annuity benefits smaller than those paid to a similarly situated man is disparate treatment of her as an individual. ${ }^{58}$ Paying men and women equal periodic benefits may have a disparate impact on men as a group. ${ }^{60}$ Whether to proscribe disparate treatment of individuals or disparate impact on groups is the fundamental choice in civil rights policy. We argued at length in our original article that in the context of sex discrimination in compensation Congress chose to forbid only disparate treatment of individuals. ${ }^{.1}$

1. Benston's Group Equality Model. Benston's vision of statutory fairness is a strange variation on the group equality model. It is strange because of his emphasis on efficiency, an emphasis that is rejected by most advocates of group equality ${ }^{62} \mathrm{He}$ insists that the statutes require that average group differences be taken into account when it is efficient to do so, and he concludes that to do otherwise constitutes unfair and illegal discrimination..$^{68}$

propensity makes it necessary to determine why an employer has used sex and race in employment decisions. Id. at 255.

"7 Benston originally denied that his defense of sex discrimination in insurance is " $\mathrm{a}$ special case of the argument that sex discrimination is sometimes economically efficient," " Benston, supra note 1, at 511 n.61 (quoting Brilmayer, Hekeler, Laycock \& Sullivan, supra note 2, at 534-35), but he no longer disputes that this is really his argument.

se See authorities cited in Brilmayer, Hekeler, Laycock \& Sullivan, supra note 2, at 528 n.110.

Id. at 508-11.

$\infty$ Id.

62 Id. at 514-23.

(3)e, e.g., Blumrosen, Strangers in Paradise: Griggs v. Duke Power Co. and the Concept of Employment Discrimination, 71 MrcH. L. REv. 59, 81-89, 100-07 (1972).

as Benston, supra note 1 , at 505-06, 508-12, 525, 542. Benston occasionally implies that he, too, pursues individual equality, $i d$. at $493,495,507,509$, but these claims are based on his fallacious assertion that group averages are individual characteristics for every member of the group, see supra notes 34-40 and accompanying text. He eventually drops the facade 
Although Benston explicitly assumes that conclusion, he never defends it. In an introductory section entitled "Underlying Assumptions," he assumes that "the law does not prevent employers from distinguishing among individuals with regard to [race, color, religion, sex, and national origin] as long as the distinctions are demonstrably germane to the tasks for which a person is employed and do not mask otherwise illegal discrimination." this assumption on a recognition that individuals naturally differ and that some of these individual differences may be related to race, color, religion, sex, and national origin."6s Thus, "demonstrably germane" does not mean relevant in and of itself; it means statistically associated. And "otherwise illegal discrimination" apparently means irrational or self-interested bigotry. ${ }^{68} \mathrm{~A}$ subsequent section on the statutes incorporates and extends this assumption; he ultimately insists that not to take race or sex into account is to discriminate, ${ }^{67}$ but nowhere does he offer any analysis that supports the assumption.

He does attempt to support his conclusion about the statute's requirements by citing four other articles, ${ }^{68}$ but their authors disagree so much with him and with each other that the citations merely demonstrate his own confusion about civil rights policy. Professors Kimball and Rutherglen give Benston the most support, but we have already responded to their arguments, ${ }^{69}$ and Benston makes no effort to rehabilitate or extend their analyses. Moreover, Rutherglen finds group equality attractive only in theory; he abandons the model as unworkable in practice. ${ }^{70}$ Thus, he rejects Benston's conclusion."1 Benston also purports to rely on Professor Wasserstrom, but Wasserstrom presents a radically individualistic theory wholly inconsistent with Benston's assumptions and conclusion. ${ }^{72}$

and explicitly compares payouts to groups. Benston, supra note 1 , at $517 \mathrm{n} .72$.

Benston, supra note 1, at 493.

es Id.

See Benston, supra note 11, at 252, 254-55, 263.

- Bz Benston, supra note 1, at 505-12.

8 Freed \& Polsby, Privacy, Efficiency, and the Equality of Men and Women: A Revisionist View of Sex Discrimination in Employment, 1981 AM. B. Found. RESEARCH J. 583; Kimball, supra note 7; Rutherglen, supra note 10; Wasserstrom, Racism, Sexism, and Preferential Treatment: An Approach to the Topics, 24 U.C.L.A. L. REv. 581 (1977). Benston's citations appear in Benston, supra note 1, at $493 \mathrm{nn} .17-19,507-08 \mathrm{nn} .53-55$.

- Brilmayer, Hekeler, Laycock \& Sullivan, supra note 2, at 508-39.

zo Rutherglen, supra note 10, at 248-56.

72 Benston finds this "difficult to understand." Benston, supra note 1, at 509 n.55.

72 Wasserstrom would judge nondiscrimination policy by whether it helps move society toward "the assimilationist ideal." Wasserstrom, supra note 68, at 615-16. A radical version 
Finally, Benston cites Professors Freed and Polsby, who collect a disparate set of cases and hypotheticals on sexual privacy, sexual entertainment, dramatic authenticity, grooming codes, and physical safety, ${ }^{73}$ and infer that employment decisions on the basis of sex are justified "where a strong enough efficiency justification is present and where the claim of an individual for individual treatment is weak or diffused."'7 Their analysis is quite different from Benston's, however, and lends him little support. ${ }^{75}$ Benston asserts that the nondiscriminatory ideal requires that race and sex be taken into account, ${ }^{76}$ but that efficiency considerations can override the ideal. ${ }^{77}$ Freed and Polsby say just the opposite. They say that blindness as to sex and race and equal treatment of individuals are the nondiscriminatory ideal, ${ }^{78}$ but that efficiency considerations can override the ideal in the case of sex. ${ }^{29}$ Thus, Freed and Polsby agree with Benston that efficiency is sometimes more important than nondiscrimination, but on the key to his whole position, the choice between the two models of equality, they, too, disagree with him. ${ }^{80}$ Consequently, his whole article depends on his

of the individual model of equality, "the assimilationist ideal" is a society in which sex would be as irrelevant as eye color, sexual preference would be anomalous, and "bisexuality . . . would be the norm." Id. at 606 . The assimilationist ideal "require[s] the eradication of all sex-role differentiation." Id. One who would eliminate gender distinctions in bed surely would not preserve them in actuarial tables.

${ }^{73}$ Freed \& Polsby, supra note 68, passim.

It Id. at 636.

${ }^{78}$ A complete response to Freed and Polsby must wait, but the outlines for such a response are clear. We already have analyzed most of the exceptions to sex-blindness on which they rely, see Brilmayer, Hekeler, Laycock \& Sullivan, supra note 2, at 524-25, as well as their general efficiency exception, id. at 533-35; see also supra text accompanying notes 48-55. We also note the gulf between their scattered data and their sweeping generalizations.

76 Benston, supra note 1, at 493, 494 n.23, 505-06, 508-12, 517, 525.

72 Id. at 498-501, 512, 532 n.135.

78 Freed \& Polsby, supra note 68, at 588, 622-23.

70 Id. at 588-89, 613-24, 630 .

so This conceptual disagreement is not merely theoretical; it has several important implications. Benston believes that the employment discrimination laws require gender-specific actuarial tables. Benston, supra note 1; at 505-06. Freed and Polsby would merely permit them as an option. Freed \& Polsby, supra note 68, at 623-24, 630. Benston would apply his group-based model of equality to race as well as sex. Benston, supra note 1, at 511-12. Freed and Polsby believe that nothing can override the individual model of equality with respect to race. Freed \& Polsby, supra note 68, at 615 . Benston believes that any correlation, however slight, between the trait predicted and race or sex requires employers to take race or sex into account, unless it is too costly to do so. Benston, supra note 1, at 498-501, 512. Freed and Polsby would allow sex to be considered only when the employer can prove that "the advantage of using sex as a decision criterion is substantial." Freed \& Polsby, supra note 68, at 614. Finally, Freed and Polsby base their arguments on the bona fide occupational qualification exception to Title VII, 42 U.S.C. $\$ 2000$ e-2(e) (1976), which they 
own bare assumptions, and our showing that the statutes require equal treatment for individuals, rather than for groups, remains unrebutted.

2. The Individual Equality Model. With respect to insurance fringe benefits, the individualist model of equality requires that insurers calculate life expectancies and pay benefits without regard to sex; a woman and a similarly situated man should make the same payments and receive the same benefits. Race and sex cannot be used as proxies for some other variable-such as longevity-even if it is efficient to do so. ${ }^{81}$ In our original article, we reviewed the reasons for this stringent prohibition on the use of race and sex as predictors, ${ }^{82}$ and one of us since then has analyzed those reasons in greater detail..$^{\mathbf{3}}$ Because sex and race are immutable, irrelevant to distinguishing between otherwise identical individuals, and historically abused as classifiers, any use of race or sex to predict employment-related traits is forbidden. ${ }^{84}$ Whenever race or sex is used as a predictor, some individuals are disadvantaged because of a stereotype that is true of others, but not of themselves. ${ }^{85}$

Benston does not claim that employers have based annuity decisions on sex inadvertently. They do it intentionally, and Benston vigorously defends their right to continue that practice. Rather, his claim is that employers have a legal justification for making insurance fringe benefit decisions on the basis of sex. ${ }^{86}$ The statute recognizes no such justification, however, other than the bona fide occupational qualification defense ${ }^{87}$ which plainly is not applicable here ${ }^{88}$ Whatever the merits of Benston's justification argument, it

concede only applies to job qualifications. Freed \& Polsby, supra note 68, at 631 . They diffidently suggest that a more general efficiency exception that would include compensation might be implied, and conclude that if that notion were to be rejected, Manhart was correctly decided but should be legislatively overruled. Id. In contrast, Benston confidently asserts that Manhart was wrongly decided. Benston, supra note 1 , at 492 . He relies not on any statutory exception, but on his definition of the discrimination prohibited by Title VII, 42 U.S.C. § 2000e-2(a)(2) (1976). Benston, supra note 1, at 505-07.

as See Brilmayer, Hekeler, Laycock \& Sullivan, supra note 2, at 526-33.

${ }^{82}$ Id.

${ }^{83}$ Laycock, Taking Constitutions Seriously: A Theory of Judicial Review (Book Review), 59 Tex. L. Rev. 343, 382-88 (1981).

st Benston initially seemed to acknowledge that these three facts bolster the argument for stringent prohibitions on the use of race and sex as decision criteria. Benston, supra note 1, at 509-11. In his response, he shifts to the position that sex and race are no different from any other predictive variables. Benston, supra note 11, at 250, 254, 258, 263.

ss Brilmayer, Hekeler, Laycock \& Sullivan, supra note 2, at 539 n.166.

${ }^{83}$ See Benston, supra note 1, at 505-12.

${ }^{87} 42$ U.S.C. $\$ 2000 \mathrm{e}-2(\mathrm{e})$ (1976).

88 See supra note 80. 
has nothing to do with intent. Employers intend to do exactly what they in fact do, which is to pay smaller periodic annuities to women than to men. Discriminatory intent is incontestably proven whenever there is an explicit sexual classification. The "legitimate nondiscriminatory reason" mandated by the case law ${ }^{89}$ must be a reason other than sex, not an asserted justification for a decision based squarely on sex. Because sex is an explicit criterion in sexdistinct mortality tables, use of such tables in the calculation of fringe benefits violates the applicable civil rights laws.

\section{An Update on the Demographic Evidence}

Every individual has a right not to be treated as the average member of his sex or race. Even if part of the SMD is biologically caused, it does not follow that a man and a woman who differ only by sex will have different longevity. To prove that, Benston must identify some genetic or biological difference that affects every member of a sex and that affects the longevity of every individual equally. ${ }^{\circ 0}$ Only then would it be possible to say of two persons, identical except for sex, that one would live a specific number of months or years longer than the other..$^{91}$ No one, however, has offered any evidence of a factor that uniformly affects the longevity of every individual on the basis of sex. Indeed, both sides now agree that the argument over a genetic or biological advantage is legally irrelevant..$^{92}$ Manhart's critics have used such biological arguments rhetorically to bolster the appeal of their efficiency and fairness claims; rhetoric aside, however, Kimball and Benston largely have conceded our evidence that the SMD has varied by century, by country, and by region and state within the United States. ${ }^{93}$ They also concede that a predictor is efficient only if past

so See, e.g., Texas Dep't of Community Affairs v. Burdine, 450 U.S. 248, 256 (1981).

- See Brilmayer, Hekeler, Laycock \& Sullivan, supra note 2, at 539 n.166.

21 If such a causal connection were to be established, there might be an arguable justification for taking the SMD into account in the calculation of annuity premiums and benefits. Even then, however, there would be some justification for spreading the differing costs of longevity over the whole population, just as Congress spread the cost of pregnancy in employer-sponsored health and disability insurance. See 42 U.S.C. \& $2000 \mathrm{e}(\mathrm{k})$ (Supp. V 1981). The analogy is imperfect because maternity does not affect every woman equally.

${ }_{22}$ Compare Benston, supra note 11, at 267 with Brilmayer, Hekeler, Laycock \& Sullivan, supra note 2 , at 538-39 and supra notes 56-84 and accompanying text.

os The data that demonstrate this variation appear in Brilmayer, Hekeler, Laycock \& Sullivan, supra note 2, at 542-49. For the concessions, see Benston, supra note 1, at 526; Kimball, supra note 38, at 918-20. Despite Benston's unsupported hints to the contrary, see Benston, supra note 1 , at 500 , we previously have shown that this variation is not due to mere shifts in maternal mortality, Brilmayer, Hekeler, Laycock \& Sullivan, supra note 2, at 
correlations persist throughout the period in which the predicted event could occur. ${ }^{94}$

We disagree, however, on three related issues: the strength of the evidence for a biological difference in longevity after age one, the stability of the SMD over the time span that Benston believes is relevant, and the validity of assuming that today's SMD will prevail in the future. Benston's own data undercut his argument; they indicate a fluctuating correlation between sex and mortality in the past.95 Data more recent than his confirm that the relationship between sex and mortality continues to fluctuate, particularly for persons aged fifty and older. ${ }^{96}$ Such an unstable SMD means that sex is not even a reasonable predictor of the longevity of groups.

\section{A. The Biological Difference in Longevity}

Research has shown that it is difficult, if not impossible, to determine the relative magnitude of any biological component of the SMD. ${ }^{97}$ The researchers who conclude that there is a biological component believe it to be small, ${ }^{98}$ and our critics have acknowl-

544-45, 552-54; see R. Retherford, The Changing Sex Difperential in Mortality 59-69 (1975). We agree with Kimball that infant mortality is markedly higher for males, except where female infanticide is tolerated, compare Brilmayer, Hekeler, Laycock \& Sullivan, supra note 2, at 544 with Kimball, supra note 7, at 113, but both sides also agree that infant mortality is of little concern in the pension context, see Benston, supra note 1, at 526.

* Benston, supra note 1, at 513; see Kimball, supra note 7, at 108; Kimball, supra note 38 , at 919.

${ }^{25}$ See infra notes 117-22 and accompanying text.

- See infra notes 124-44 and accompanying text.

97. Waldron, The Role of Genetic and Biological Factors in Sex Differences in Mortality 21-25 (December 1981) (unpublished paper presented at a conference sponsored by the World Health Organization and Australian National University, Sex Differentials in Mortality: Trends, Determinants and Consequences, Canberra, Australia, on file with The University of Chicago Law Review).

os See Pressat, Surmortalité biologique et surmortalité sociale, 14 Revue Française DE Socrologre 103, 105 (Numero Special 1973). For further commentary on Pressat, see Brilmayer, Hekeler, Laycock \& Sullivan, supra note 2, at 547 n.207. Similar conclusions by other investigators are cited in id. at 541 n.177. Benston relies upon quotations from an introductory genetics text, A. Scheinfeld, Your Heredity and ENvironment 218-19 (1965), to the effect that females are better constructed genetically than are males. Benston, supra note 1 , at 520. He omits Scheinfeld's statements in the same passage that environment has an "important, if not predominant, influence . . . on the causes of death in the two sexes," A. ScheINPELD, supra, at 220, and that "[u]ndoubtedly, environmental factors play a growing part in creating most of this enormous disparity [in mortality] between the sexes after early childhood," id. at 218 . If Scheinfeld places somewhat more emphasis on genetic causes than we do, that simply may reflect his lack of access to the vast body of research compiled since he published his text in 1965. Our earlier article alone cited at least 65 data sources and research studies published since 1965. See generally Brilmayer, Hekeler, Laycock \& 
edged the existence of the most telling evidence of a substantial environmental influence on the SMD-its great variation over time and space. ${ }^{28}$

To assess the importance of biological causes, one line of research attempts to control for environmental factors. Among the earliest of these studies was Madigan's study of Catholic nuns and Brothers, ${ }^{100}$ which Benston discusses in some detail. ${ }^{101}$ As we previously noted, more recent studies have concluded that Madigan's research design was flawed by the fact that the Brothers had access to liquor and cigarettes. ${ }^{102}$ Benston's efforts to rehabilitate Madigan's study ${ }^{103}$ with speculations about the Brothers' smoking habits are unsuccessful. Benston compares the life expectancy of Brothers to that of male smokers, male nonsmokers, and the male population in general in order to show that the Brothers could not have been smoking enough to invalidate Madigan's results. ${ }^{104}$ The most obvious flaw in this analysis is its circularity: Benston starts with Madigan's results (the mortality experience of the Brothers), uses them to infer that smoking must have been relatively controlled, and uses that conclusion to infer that Madigan's results must have been valid. If we already knew the "natural" relationship between the longevity of the nuns and Brothers, we could draw inferences about their environment from Madigan's results. Likewise, if we knew their environment, we could draw inferences about their "natural" longevity. But we cannot infer both without knowing either, which is what Benston attempts to do. ${ }^{105}$

Sullivan, supra note 2, passim. Moreover, most of Scheinfeld's data that suggest a genetic component in the SMD relate only to infant mortality. A. ScHBINFELD, supra, at 219 (Table III).

- See supra note 93 and accompanying text.

100 Madigan, Are Sex Mortality Differentials Biologically Caused?, 35 Mrlbank MemoRial Fund Q. 202 (1957); Madigan \& Vance, Differential Sex Mortality: A Research Design, 35 SOC. Forces 193 (1957).

${ }^{101}$ Benston, supra note 1 , at 520-23.

102 Brilmayer, Hekeler, Laycock \& Sullivan, supra note 2, at 550 \& n.228; see Waldron, An Analysis of Causes of Sex Differences in Mortality and Morbidity, in The Fundamental Connection Between Nature and Nurture 69, 105 n.4 (W. Gove \& G. Carpenter eds. 1982). Madigan, who admitted that Brothers were likely to smoke and drink, Madigan, supra note 100 , at 204 , also noted that overeating and obesity were not controlled, id. at 205.

${ }^{103}$ Benston, supra note 1 , at 521-23.

${ }^{104} I d$. at 522-23 \& n.94. He compares the data for the Brothers at age 35 during 195054 with data for male smokers, nonsmokers, and the male population at age 37 during 195964. Id.

105 Perhaps Benston is assuming that the Brothers were like the male population except for smoking, but that assumption is not supported by the data. In 1950-54, at age 37 , the Brothers' expectation of life was 35.7 years, compared to 34.1 years for white males gener- 
A close reading of Madigan's study suggests that other environmental factors were also at work. For example, young Sisters had higher mortality rates in the first two decades of this century than did either Brothers or native-born white women of similar age. ${ }^{106}$ Both Madigan and Benston surmise that this higher death rate could have been caused by tuberculosis in the convents. ${ }^{107}$ The Sisters who survived this unhealthy environment were apparently hardier or more resistant to disease than the Sisters who had succumbed. It is these hardy survivors whose later mortality experience was so much better than that of the Brothers, and indeed, better than that of the white female general population. ${ }^{108}$ The mortality experience of these individuals proves nothing about women in general.

More to the point, a group of more recent studies have attempted to control for environment. When at least some important environmental factors are controlled, the SMD for the group stud-

ally, a difference of 1.6 years. (These data were interpolated from Madigan, supra note 100, at 213 (Table 1). Madigan's data reflected life expectancies for Brothers at ages 25, 35, 45, etc. Two-tenths of the difference in mortality between age 35 and 45 were subtracted from the expectancy for age 35 to produce the life expectancy for a Brother at age 37.) In 195964 , the life expectancy for nonsmoking males at age 37 was 39.9 years, compared to 37.2 years for the male population generally, a difference of 2.7 years. Benston, supra note 1 , at 523 n.94 (citing R. RETHERford, supra note 93, at 75 (Table 14)). Thus, the Brothers had a longer life expectancy than the white male population, but not nearly as much longer as that of nonsmokers. Moreover, at ages 65 and over, which Benston insists are the ages that matter the most for purposes of annuity benefit calculations, Benston, supra note 1, at 517, 526, the Brothers' life expectancy was shorter than the white male population's. Madigan, supra note 100 , at 213 (Table 1). This crossover-the fact that the young Brothers had a longer life expectancy than the population and the older Brothers a shorter one-itself suggests that an important environmental factor was at work. Moreover, Benston's data on per capita national consumption of cigarettes, Benston, supra note 1, at $523 \mathrm{n.94}$, tell nothing about smoking habits among the Brothers.

${ }^{108}$ Madigan, supra note 100, at 216 (Table 3).

${ }^{107}$ Benston, supra note 1, at 521 n.87; Madigan, supra note 100, at 217-18.

${ }^{103}$ In every cohort that could be traced to age 65 , the Sisters were survivors of a group that had had higher mortality than Brothers of similar age:

Decade in which cohort

was age 65-74

Decades in which that cohort had higher mortality among

1950-54

$1940-49$

1930-39

1920-29

nuns than among Brothers

1900-29 (age 15-44)

1900-19 (age 25-44)

1900-09 (age 35-44)

1910-19 (age 55-64)

These data are taken from Madigan, supra note 100, at 216 (Table 3). No cohort of other white women that could be traced to age 65 had a similar history. Id. The theoretical and empirical case for this cohort analysis was made by Vaupel, Manton \& Stallard, The Impact of Heterogeneity in Individual Frailty on the Dynamics of Mortality, 16 DEMograpHy 439 (1979). 
ied has been substantially smaller than that for the general population. ${ }^{108}$ Such studies have been conducted on nonsmokers, ${ }^{110} \mathrm{Sev}$ enth-Day Adventists (for whom smoking and alcohol are prohibited), ${ }^{111}$ Mormons (for whom alcohol, tobacco, and caffeine are prohibited), ${ }^{112}$ and alcoholics (who, regardless of sex, have similar habits of heavy drinking and smoking). ${ }^{113}$ Even Madigan's data show that for more than half of the age groups and decades studied, the SMD between nuns and Brothers was smaller than that for the population generally. ${ }^{114}$ None of these studies controls for all possible environmental influences, and therefore they do not measure completely the relative influence of biological and environmental factors. Such a perfect measure probably is impossible, but the growing body of research suggests that environmental and behavioral factors predominate. Even Benston acknowledges Professor Waldron's conclusion, after her review of 163 scientific papers, that behavioral differences are more important than are biological differences in their effects on life expectancy. ${ }^{115}$

\section{B. Stability of SMDs Over Short Periods}

Benston argues that, in establishing the stability of the SMD for pension purposes, the relevant period is the fifteen to twentyfive years that elapse between retirement and death. ${ }^{116}$ His own

108 I. Waldron, supra note 97, at 22-23.

110 Hammond, Smoking in Relation to the Death Rates of One Million Men and Women, 19 Nat'l Cancer Inst. Monograph 127, 166-69 (1966); Waldron, Why Do Women Live Longer than Men?, 10 Soc. ScI. \& MED. 349, 350 (1976) (Table 2) (showing lower sex mortality ratios for nonsmokers than for general population).

11 Phillips, Kuzma, Beeson \& Lotz, Influence of Selection Versus Lifestyle on Risk of Fatal Cancer and Cardiovascular Disease among Seventh-Day Adventists, 112 Am. J. EPIDEMIOLOGY 296, 304-05 (Table 4) (1980).

112 Jarvis, Mormon Mortality Rates in Canada, 24 Soc. Brology 294 (1977). See generally Enstrom, Cancer and Total Mortality Among Active Mormons, 42 CANCER 1943 (1978) (lower mortality among active Mormon males than for males generally).

113 Schmidt \& Popham, Sex Differences in Mortality: A Comparison of Male and Female Alcoholics, 5 Rrsearch Advances Alcohol \& Drug Probs. 365, 381-82 (1980).

11 This was true for all ages in 1900-19, for ages 15 and 25 in 1920-29, for age 15 in 1930-39, and for all ages except 55 in 1940-49. Madigan, supra note 100, at 213 (Table 1). Even for the pooled data for 1900-54, the Sister/Brother SMD was smaller than the national white SMD at ages 15 and 25. Id. at 214 (Table 2). Analyses of ratios of life expectancies, id. at 213-14 (Tables $1 \& 2$ ), and differences and ratios of mortality rates, $i d$. at 216 (Table 3), produce similar results. Benston reaches a different conclusion by omitting all ages under 65 and the decade before 1910. Benston, supra note 1, at 521-22. Thus he examines only the ages that are distorted by the survivorship effect described supra notes 106-08 and accompanying text.

118 Benston, supra note 1 , at 523 (citing Waldron, supra note 110, at 358).

116 Id. at $517,526$. 
data, however, show instability over this period. Table B contains TABLE B

Expectation of Life at Age 65, by Sex, for U.S. Whites, 1900-1979

\begin{tabular}{|c|c|c|c|c|}
\hline Year & Males & Females & $\begin{array}{c}\text { Difference } \\
(\mathbf{F}-\mathbf{M}) \\
\end{array}$ & $\begin{array}{l}\text { Ratio } \\
(\mathrm{E} / \mathrm{M}) \\
\end{array}$ \\
\hline 1979 (preliminary) & 14.3 & 18.7 & 4.4 & 1.31 \\
\hline 1978 & 14.0 & 18.4 & 4.4 & 1.31 \\
\hline 1977 & 13.9 & 18.4 & 4.5 & 1.32 \\
\hline 1976 & 13.7 & 18.1 & 4.4 & 1.32 \\
\hline 1975 & 13.7 & 18.1 & 4.4 & 1.32 \\
\hline 1974 & 13.4 & 17.6 & 4.2 & 1.31 \\
\hline 1973 & 13.2 & 17.3 & 4.1 & 1.31 \\
\hline $1969-71$ & 13.0 & 16.9 & 3.9 & 1.30 \\
\hline $1959-61$ & 13.0 & 15.9 & 2.9 & 1.22 \\
\hline $1949-51$ & 12.8 & 15.0 & 2.2 & 1.17 \\
\hline $1939-41$ & 12.1 & 13.6 & 1.5 & 1.12 \\
\hline $1929-31^{a}$ & 11.8 & 12.8 & 1.0 & 1.08 \\
\hline $1919-21^{a}$ & 12.2 & 12.8 & 0.6 & 1.05 \\
\hline $1909-11^{a}$ & 11.2 & 12.0 & 0.8 & 1.07 \\
\hline $1900-02^{a}$ & 11.5 & 12.2 & 0.7 & 1.06 \\
\hline
\end{tabular}

a Figures rounded to three digits

Sources: Taken or derived from Bureau of the Census, U.S. Dep't of Commerce, StatistiCal AbStract of the United States 55 (88th ed. 1967) (Table 63); id. at 53 (90th ed. 1969) (Table 67); id. at 60 (97th ed. 1976) (Table 86); id. at 69 (99th ed. 1978) (Table 99); id. at 70 (100th ed. 1979) (Table 101); id. at 72 (101st ed. 1980) (Table 107); id. at 69 (102d ed. 1981) (Table 106). We have limited our data to whites to maintain comparability with the data presented by Benston.

the data Benston cites. ${ }^{117}$ Benston notes that between 1949-51 and 1975 the SMD at age sixty-five increased "only" 2.2 years, ${ }^{118}$ but this is from a base of 2.2 years and thus represents a $100 \%$ change. ${ }^{119}$ Between 1939 and 1959 there was a 93\% increase; between 1949 and 1969 there was a 77\% increase; between 1959 and 1979 there was a $52 \%$ increase. In the short period from 1969 to 1979 , there was a $13 \%$ increase. Even during the last few decades,

${ }^{117}$ Id. at 527 (Table 4). We have extended the periods and cited the original sources from which his data are derived.

118 Id. at 526.

129 Of course, it is $100 \%$ of a small initial difference, but the proponents of segregated tables claim it is important to predict such small differences. Id. at 498-500. As we have said already, "the magnitude of potential errors is enormous in proportion to the difference being predicted." Brilmayer, Hekeler, Laycock \& Sullivan, supra note 2, at 559 (footnote omitted). 
controlling for age and race within a small part of the human life span, there is little sign of stability in the SMD. ${ }^{120}$

Unable to demonstrate that the SMD itself is stable, Benston claims that changes in the SMD are predictable. He states that after 1921, the SMD at age sixty-five was "always increasing by about the same amount per decade." ${ }^{21}$ The data in his Table 4, however, do not support that assertion; during the decades since 1921, there have been two increases of half a year, two of seventenths of a year, and one of a full year. ${ }^{122}$ This last change is $100 \%$ larger than the earlier changes. In the two pre-1921 decades that Benston excludes from his analysis, he reports that the SMD at age sixty-five declined by two-tenths of a year. ${ }^{123}$ Benston's table omits data for the years 1971-79 that show more evidence of instability. The SMD at age sixty-five jumped half a year between 196971 and 1975; it fluctuated with no net change from 1975 to $1979 .{ }^{124}$ Thus, the rate of change in the SMD appears as unstable as the SMD itself.

Finally, Benston errs in asserting that only the retirement-todeath period is of interest in the pension context. ${ }^{125}$ The number of survivors to age sixty-five is also important, because that is the denominator in estimating life expectancy. ${ }^{126}$ As Table $\mathrm{C}$ shows, even within a short period, there is also considerable variation in this datum. Between 1959 and 1969, the number of men who could

120 Benston attempts to minimize the appearance of instability by netting out offsetting changes. Benston, supra note 1, at 527 (Table 4). If the decline in the SMD from 1910 to 1920 is counted as a change, rather than as offsetting a later change in the opposite direction, the cumulative change in the SMD between 1900 and 1971 is 3.6 years. Benston's figure is 3.2 years. $I d$.

121 Id. at 527.

122 Id. (Table 4).

123 Id.

124 See supra Table B.

123 Benston, supra note 1 , at 520,526. His implication, id. at 526, that we did not present data for older ages is also incorrect, see Brilmayer, Hekeler, Laycock \& Sullivan, supra note 2 , at $543,545,552,554$.

126 See $2 \mathrm{H}$. Shryock, J. Sizger \& Associatzs, The Methods and Materials of DeMOGRAPHY 431, 442 (1971).

Another reason, overlooked by Benston, why mortality during the employment years is important is that persons who die during those years will have contributed to the fund but will not draw a pension. In most or all defined contribution plans this is irrelevant, because the dead employee's contributions are refunded in the form of a death benefit or a survivor annuity. In defined benefit plans, however, employees who die before retirement often forfeit their contributions to the fund. Alternatively, their survivors may receive an annuity whose value exceeds what could have been funded by the worker's prematurely terminated contributions. Either way, the plan's actuaries must take account of preretirement mortality. 
be expected to reach age sixty-five actually decreased slightly; between 1969 and 1979, it increased by nearly $10 \%$; between 1969 and 1975 , there was a jump of more than $6 \%$. As we noted in our earlier article, the early 1970's saw a large and unpredicted decline in male mortality. ${ }^{127}$ The number of female survivors also increased between 1969 and 1975, but by less than $3 \%$.

\section{TABLE C}

Number of Survivors to Age 65 of 1000 Born Alive, by Sex, for

U.S. WHITES, 1959-1979

\begin{tabular}{lcccc}
\hline \hline Year & Males & Females & $\begin{array}{c}\text { Difference } \\
(\text { F-M })\end{array}$ & $\begin{array}{r}\text { Ratio } \\
\text { (F/M) }\end{array}$ \\
\cline { 2 - 3 } 1979 (preliminary) & 716 & -130 & 1.18 \\
1977 & 707 & 846 & 131 & 1.19 \\
1976 & 701 & 838 & 134 & 1.19 \\
1975 & 694 & 835 & 138 & 1.20 \\
$1969-71$ & 652 & 832 & 157 & 1.24 \\
$1959-61$ & 658 & 809 & 149 & 1.23
\end{tabular}

Sources: Taken or calculated from Bureau of the Census, U.S. Dep't of Commerce, Statistical Abstract of the United States 69 (102d ed. 1981) (Table 106); id. at 70 (100th ed. 1979) (Table 101); id. at 69 (99th ed. 1978) (Table 99). We have limited our data to whites to maintain comparability with the data presented by Benston.

The numerator for life expectancy at age sixty-five is the total number of person-years of remaining life at that age. ${ }^{128}$ As reported in Table D, during the nineteen years between 1960 and 1979 , this figure increased by $21.5 \%$ for men and $23.9 \%$ for women. During the shorter period from 1970 to 1979 , the male increase was $17.6 \%$, larger than the female increase of $13.4 \%$. Thus, for life expectancy at age sixty-five, as well as for the two constituent statistics used to calculate life expectancy, there is little sign of stability, even over as short a time as nine years.

127 Brilmayer, Hekeler, Laycock \& Sullivan, supra note 2, at 554-56. The unpredicted decline in mortality rates was one of the six major demographic "surprises" of the 1970's. Beale, Six Demographic Surprises of the 1970s, Population Bull., June 1982, at 33, 33.

128 2 H. Shryock, J. Siegel \& Associates, supra note 126, at 431, 442. 


\section{TABLE D}

Total Number of Person-Years lived After Age 65, By Sex, for U.S. WHITES, 1939-1979

\begin{tabular}{lrrrr}
\hline Year & Males & Females & $\begin{array}{c}\text { Difference } \\
(\mathrm{F}-\mathrm{M})\end{array}$ & $\begin{array}{r}\text { Ratio } \\
\text { (F/M) }\end{array}$ \\
$\overline{1979}$ & $1,023,880$ & $1,582,020$ & 558,140 & 1.55 \\
1977 & 982,730 & $1,541,920$ & 559,190 & 1.57 \\
1975 & 950,780 & $1,505,920$ & 555,140 & 1.58 \\
1970 & 870,847 & $1,394,954$ & 524,107 & 1.60 \\
1960 & 842,432 & $1,276,821$ & 434,389 & 1.52 \\
$1949-51$ & 810,148 & $1,151,595$ & 341,447 & 1.42 \\
$1939-41$ & 703,741 & 931,586 & 227,845 & 1.32
\end{tabular}

Sources: Taken or calculated from 2 National Center for Health Statistics, U.S. Dep'T of Health, Education \& Welfare, Vital Statistics of the United States 2-8 (1960) (pt. A) (Table 2-1); id. at 2-11 (Table 2-5); 2 id. at 5-4 (1970) (pt. A) (Table 5-1). Data for 1975, 1977, and 1979 are calculated based on the data presented supra Tables B \& C. We have limited our data to whites to maintain comparability with the data presented by Benston.

\section{Past and Future Relationships of Gender to Mortality}

The preceding tables indicate that male mortality is decreasing at a faster rate than is female mortality. Moreover, most of this improvement is occurring at the older ages. Between 1975 and 1980 the expectation of life at birth improved by $1.6 \%$ for men and $1.2 \%$ for women; during the same period, the SMD at birth declined slightly from 7.8 to 7.6 years. ${ }^{128}$ At age sixty-five, the 197579 increase in life expectancy was $4.4 \%$ for men and $3.3 \%$ for women. ${ }^{130}$ For the same period, the improvement in numbers of survivors to age sixty-five was $3.2 \%$ for men, $1.7 \%$ for women; ${ }^{131}$ the increase in total number of person-years lived after age sixtyfive was $7.7 \%$ for men and $5.1 \%$ for women. ${ }^{132}$ For each of these measures, the rate of increase in longevity is greater for men than for women.

Another approach to analyzing this phenomenon is to examine, as Benston does, mortality rates by sex. ${ }^{133}$ Such analysis, however, is confounded by the level effect. The level effect is the

120 Compare Bureau of the Census, U.S. Dep't of Commerce, Statistical Agstract of the United States 69 (102d ed. 1981) (Table 106) with U.S. Population: Where We Are; Where We're Going, Population Buld., June 1982, at 16, 16.

${ }^{130}$ Calculated from Table B, supra.

131 Calculated from Table C, supra.

${ }^{132}$ Calculated from Table D, supra.

${ }^{333}$ See Benston, supra note 1, at 516 (Table 2), 522 (Table 3). 
phenomenon that as the overall level of mortality declines and the difference in mortality rates by sex declines, the ratio of those rates rises. ${ }^{134}$ All but one of Benston's tables are susceptible to the level effect because they compare ratios rather than differences. ${ }^{235}$ An examination of the differences in rates suggests greater male improvement. For example, between 1979 and 1980, the age-adjusted death rate for women actually increased by nearly $2 \%$, while the same rate for men increased by just under $1 \% .{ }^{136}$ More generally, two analyses of recent mortality rates concluded that the rate of increase in the SMD is slowing, with perhaps a stabilization or decline in the offing. ${ }^{137}$ This conclusion was confirmed by a 1982 study that used orthogonal regression analysis, ${ }^{138}$ a technique that can overcome the level effect.

A more analytic method of studying changes in the SMD would be to examine the differences in the leading causes of death

${ }^{134}$ See S. Preston, Mortality Patterns in National Populations 127 (1976). An example of the level effect can be shown with the following hypothetical data:

\begin{tabular}{|c|c|c|c|c|}
\hline \multirow[b]{2}{*}{ Period } & \multicolumn{2}{|c|}{ Mortality Rates } & \multirow{2}{*}{$\begin{array}{c}\text { Difference } \\
(\mathrm{M}-\mathrm{F}) \\
\end{array}$} & \multirow{2}{*}{$\begin{array}{l}\text { Ratio } \\
(\mathrm{M} / \mathrm{F}) \\
\end{array}$} \\
\hline & Males & Females & & \\
\hline 1 & 100 & 40 & 60 & 2.5 \\
\hline 2 & 60 & 20 & 40 & 3.0 \\
\hline 3 & 40 & 10 & 30 & 4.0 \\
\hline
\end{tabular}

The ratio of male to female mortality rates increases over time, although the difference decreases.

We earlier mentioned the mischievous effect of using selective mortality measures such as ratios of mortality rates. Brilmayer, Hekeler, Laycock \& Sullivan, supra note 2, at $\mathbf{5 4 2}$ n.183. We also noted that orthogonal regression might be used, thereby avoiding such problems, id. at 548 , and pointed out an illustrative error attributable to the level effect, $i d$. at 554 n.260.

${ }^{135}$ See Benston, supra note 1, at 515 (Table 1), 516 (Table 2), 522 (Table 3), 523 n.94. Only his Table 4, id. at 527, compares differences between rates.

${ }^{138}$ Annual Summary of Births, Deaths, Marriages, and Divorces: United States, 1980, Nat'c Center for Health Statistics, Monthi.y Vital Statistics Rep., Sept. 17, 1981, at 1, 4.

${ }^{137}$ Graney, An Explanation of Social Factors Infuencing the Sex Differential in Mortality, Soc. Symp., Fall 1979, at 19 (predicting declining SMDs because of changing sex roles and the earlier female approach to the ultimate ceiling on longevity); Verbrugge, Recent Trends in Sex Mortality Differentials in the United States, Women \& HenLth, Fall 1980, at 17; see also U.S. Population: Where We Are; Where We're Going, supra note 129, at 41 (concluding that the SMD "is likely at least to stabilize in the 1980s rather than continuing to widen as it did from 1900 to 1968").

138 M. McMillen, The Changing Trends in Sex and Race Differentials in Mortality 8, 14 (Apr. 1982) (unpublished manuscript on file with The University of Chicago Law Review). McMillen notes that between 1968 and 1978, although the ratio of male to female death rates increased, the sex differences contracted because male death rates fell more in absolute numbers than did female death rates. Id. at 7. 
of men and women..$^{139} \mathrm{We}$ previously have noted the increasing female mortality from lung cancer. ${ }^{140}$ A study of deaths occurring between 1968 and 1978, from causes of major importance to the retirement age population, shows that the SMD has decreased for cerebrovascular diseases, ulcers, motor vehicle accidents, and all other accidents. ${ }^{111}$ Mortality from automobile accidents has been decreasing for men over sixty-five while increasing for women over sixty-five. ${ }^{142}$ Sex differences in death rates from cirrhosis of the liver have decreased for whites, although not for blacks. ${ }^{143}$ Only for malignant neoplasms (all sites) is the SMD increasing. ${ }^{144}$

All major causes of death that contribute to the SMD have important behavioral components. ${ }^{145}$ Benston correctly quotes Waldron's statement that these behaviors will be difficult for men to change, ${ }^{148}$ but he omits her finding that many women now are adopting these behaviors. ${ }^{147}$ Barring a new infectious disease or a major conventional war, individual behavior is likely to continue to

199 See generally Brilmayer, Hekeler, Laycock \& Sullivan, supra note 2, at 552-54.

${ }^{140}$ Id. at 555 n.264; see also Waldron, supra note 102, at 86 (finding that sex ratios have declined substantially in recent years for cancers of the respiratory system).

${ }^{141}$ M. McMillen, supra note 138, at 10, 12-13, 20 (Table 6).

${ }^{142}$ Veevers, Women in the Driver's Seat: Trends in Sex Differences in Driving and Death, 1 Population Research \& Pol'y Rev. 171, 176 (1982) (Table IV) (data from 195073); see also M. McMillen, supra note 138, at 20 (Table 6) (similar finding for all ages with 1968-78 data).

${ }^{143}$ M. McMillen, supra note 138, at 20 (Table 6); see also Krasner, Davis, Portmann \& Williams, Changing Pattern of Alcoholic Liver Disease in Great Britain: Relation to Sex and Signs of Autoimmunity, 1977 BRIT. MED. J. 1497 (increasing proportion of patients with alcoholic liver disease are women, and women patients have lower survival rates than men).

114 M. McMillen, supra note 138, at 20 (Table 6). Note, however, that the male/female ratios of the rates increase for cirrhosis and accidental deaths among whites. $I d$. at 13,20 (Table 6). This is another example of the level effect. See supra note 134 and accompanying text.

${ }^{145}$ Waldron, supra note 102 , at 72 . The SMD is highest for the seven causes of death with major behavioral components: homicide, suicide, motor vehicle accidents, other accidents, lung cancer and emphysema, which are both closely linked to cigarette smoking, and cirrhosis of the liver, which is related to excessive alcohol consumption. Id.

${ }^{348}$ Benston, supra note 1 , at 523 (quoting Waldron, supra note 110 , at 358).

167 Waldron, supra note 110 , at 357 .

Smoking-related diseases require several decades to develop. A recent Surgeon General's report notes "the first signs of an epidemic of smoking-related disease among women," "Sulzberger, Surgeon General Says Lung Cancer In Women Increases Dramatically, N.Y. Times, Jan. 15, 1980, at A1, col. 1, and the proportions of smokers among males and females age 17 to 24 are now substantially equal, Burgau or THE Census, supra note 129, at 123 (Table 202). Similarly, between 1976 and 1979, alcohol usage increased faster among women age 12 to 25 than it did among men of the same ages. Id. at 122 (Table 200). See also Ortmeyer, Female's Natural Advantage? Or, the Unhealthy Environment of Males?: The Status of Sex Mortality Differentials, Women \& Heatth, Summer 1979, at 121, 130-31. 
be an important determinant of the SMD, and this is one key reason for the unpredictability of the SMD in future years. Even if these behavior patterns were relatively stable, a sex stereotype based on them would be no less a stereotype when applied to individuals it does not describe. The reluctance of some men to change their self-destructive behavior is no reason to impute that behavior to other men.

Benston's major argument on predictability is that the current sex-specific actuarial tables have enabled accurate "prediction" in the past. ${ }^{148} \mathrm{He}$ offers Table 1 as proof. ${ }^{149}$ Table 1, however, proves very little, and what it does prove is not helpful to Benston. Table 1 has three pairs of columns showing the accuracy with which the mortality of male and female annuitants from 1960 to 1967 was "predicted" by 1949, 1963, and 1971 actuarial tables. Two of these pairs of columns, however, have nothing to do with prediction. The 1963 actuarial table was constructed from mortality experience between 1960 and $1967^{150}$ - the very period being "predicted." Benston's claim of "almost perfect[]" prediction" is based on a comparison of two measures of the same experience. The 1971 columns reflect the actuaries' estimates of how much the 1960-67 experience should be adjusted to account for expected future mortality declines. ${ }^{162}$ These columns show that insurance industry actuaries thought that the adjustments should be about the same for both sexes, ${ }^{153}$ but they say nothing about how well those adjustments are working out. Benston's analysis of the 1963 and 1971 data is completely circular and proves nothing.

Only the data in the 1949 columns say anything about how well insurers predicted the experience from 1960 to 1967. They did not predict very well, and, more damaging to Benston's argument, the errors were not neutral as to sex. For seven of the eight age groups he reports, the sex differences in the errors were substantial in comparison to the errors themselves. ${ }^{154}$

248 Benston, supra note 1, at 514.

149 Id. at 515.

${ }^{180}$ Cherry, The 1971 Individual Annuity Mortality Table, 23 Transactions Soc'y AcTUARIES 475, 486 (1971).

151 Benston, supra note 1 , at 514.

152 Cherry, supra note 150 , at $491-94$.

${ }^{163}$ Indeed, they used unisex data to predict mortality declines. Id. at 493 .

${ }^{154}$ For six of the nine age groups reported, the difference between the errors of the two sexes is greater than the total error for the more accurately predicted sex. See Benston, supra note 1, at 515 (Table 1). For seven, the difference is half or more of the average of the errors for the two sexes. Id. For example, for age $60-64$, the male error was $1 \%$, and the female error $11 \%$. Id. The difference between the two errors was $10 \%, 10$ times the male 
Actuarial tables are able to "predict" the future only if the future resembles the past. By definition, a life table is a mathematical model of the current experience of a population; ${ }^{155}$ if it is a unisex table, it mirrors the experience of a combined male and female population with no loss of "predictability." When mortality changes rapidly, a life table will be a poor predictor no matter how the data were classified initially. Predicting changes in the mortality of a population is difficult; ${ }^{156}$ predicting changes in mortality on the basis of sex is even more difficult. ${ }^{167}$ The social security board's life expectancy projections introduced in Benston's response do not even attempt to predict fluctuations in the SMD. ${ }^{158}$ The projections are based on several alternative assumptions about fertility and changes in mortality. ${ }^{159}$ The social security board reports no assumption about the SMD; it applies equivalent rates of change to existing male and female mortality rates. ${ }^{160}$ The result is no more than an extrapolation from the present SMD; it is not a prediction about the SMD.

In summary, none of Benston's statistics support his conclusions on these demographic issues. His use of the data is selective, ${ }^{181}$ and he offers sweeping factual conclusions in areas where conscientious biologists and demographers remain tentative and cautious. No one knows what the future will bring, but that is precisely the point: there is no need to permit insurance industry guesses about future developments in the SMD to override civil rights policy.

error and nearly double the average of the male and female errors (6\%). Benston's observation that the 1949 tables "yielded almost the same degree of error overall for females and for males," id. at 514, merely reflects offsetting errors among the specific age groups. Because each age group represents a different cohort, however, and each individual insured is a member of only one cohort, the sex bias in the errors is not offsetting for the individual insureds.

15s See Brilmayer, Hekeler, Laycock \& Sullivan, supra note 2, at 541-42.

180 Insurance industry actuaries agree. See Cherry, supra note 150, at 519.

157 The designers of the 1971 Individual Annuity Mortality Table used unisex data to predict future mortality declines, $i d$. at 493 , and then applied a $10 \%$ contingency factor to provide a margin for unanticipated fluctuations, id. at 494.

$2 s 8$ Board of Trustees of the Frderal Old-Age and Survivors Insurance and Disabitry Insurance Trust Funds, Annual Report (1982) [hereinafter cited as Annual RePORT], cited in Benston, supra note 11, at 271-72.

15D ANNual Report, supra note 158, at 35-36.

100 Id.

${ }^{161}$ See supra notes 118-24, 133-35, 147, 149-54 and accompanying text; notes 93, 98, 114 and 125. 


\section{Conclusion}

Even if we were to concede all of Benston's claims about the causes and stability of the SMD, it still would not follow that employers legally could use sex to predict mortality. Benston incorrectly charges that our interpretation of the statute depends on our view of the demographic evidence. ${ }^{162}$ The statute is clear, however, that sex cannot be used when it does not predict for individuals: this is what makes the demographic evidence legally irrelevant.

There are, however, three reasons why we have analyzed the demographic data anyway. Most important, misconceptions about the SMD have had substantial rhetorical impact, despite their legal irrelevance. Second, the demographic evidence shows that the cost imposed by civil rights policy in terms of forgone predictive power is slight. ${ }^{163}$ Finally, the demographic evidence shows the il-

162 Benston misunderstands our statements that sex does not predict for individuals and predicts weakly for groups. See, e.g., Benston, supra note 1, at 513 n.69 (quoting Brilmayer, Hekeler, Laycock \& Sullivan, supra note 2, at 530), 528-29 (quoting Brilmayer, Hekeler, Laycock \& Sullivan, supra note 2, at 531, 534, 539). Benston's claim that sex predicts for individuals is a reformulation of his claim that the group average is an individual's expectancy. See id. at 506 n.43, 507. Compare Kimball's more sensible statement: "no mortality table even purports to say anything about when particular individuals will die." Kimball, supra note 7, at 118 . Benston's claim that sex predicts strongly for groups appears to mean only that it predicts at least well enough to justify the small expense of taking sex into account. Compare Benston, supra note 1, at 500-01 (all individual attributes that are predictive should be used unless administrative costs exceed predictive benefits) with id. at 512 ("avoiding unfair discrimination" in theory requires that diseases related to race and ethnicity be considered in estimating risk, but these factors are disregarded in practice due to high administrative costs). Our claim that sex would be a weak predictor even if the relationship were causal and stable clearly reflects a more demanding standard. A factor that makes a seven year average difference out of a 100 year human life span is not a very strong predictor, and the instability of the relationship between sex and longevity makes the prediction that much weaker.

163 Benston's apocalyptic vision of the consequences of sexually integrated pension plans, Benston, supra note 1 , at 532-41, is inconsistent with experience with such plans and with plans ignoring other factors more strongly correlated with mortality than is sex, see Brilmayer, Hekeler, Laycock \& Sullivan, supra note 2, at 533 n.130, 535. TIAA-CREF has calculated that a "highly unlikely" "worst case" scenario of adverse selection would raise costs only $1.25 \%$. Letter from Thomas G. Walsh, Vice President and Actuary, TIAA-CREF, to James Gardiner, Supervising Actuary Life Bureau, New York State Ins. Dept. (Jan. 11, 1980) (copy on file with The University of Chicago Law Review). Other cost estimates also indicate quite manageable numbers. See Hearings on H.R. 100 Before the Subcomm. on Commerce, Transportation, and Tourism of the House Comm. on Energy and Commerce, 98th Cong., 1st Sess. 12 (1983) (statement of American Academy of Actuaries) (unpublished transcript on file with The University of Chicago Law Review) (less than 3.1\%) [hereinafter cites as Hearings]; U.S. Dep'T or Labor, Cost Study or THE Impact of an Equal Benefits Rule on Pension Benefits 5 (1983) (0.1\% to 3\%); Rabban, Developments in Equal Periodic Pension Benefits, AcADEME, Sept.-Oct. 1982, at 24, 25-26 (less than annual increase in discretionary dividends). Industry estimates of the cost of implementing sexually integrated life, health, and auto insurance, see Benston, supra note 11, at $278 \mathrm{n.80}$, do not appear to 
lusory nature of Benston's vision of fairness. Because sex is a suspect classification, even minor deviations from equality are prohibited. ${ }^{164}$ If Benston's vision of separate but equal expectancies were to be accepted as a part of civil rights policy, these expectancies would have to be measured very precisely. The patchwork of guess and projection by which the insurance industry predicts future SMDs, largely assuming stability despite the contrary history, does not even approach the necessary degree of precision. Men and women would not get equal expectancies under his system but would obtain mere guesses, with substantial errors that are not neutral with respect to sex. Thus, Benston's vision of fairness is unattainable.

It is also inconsistent with the much more appealing vision of fairness embodied in the statutes. Sex and race blindness have been the civil rights ideal. Benston's insistence on the efficient use of racial and sexual averages to predict the future of individuals is fundamentally inconsistent with that ideal, and if generally applied, would have consequences that most Americans would find abhorrent.

allow for the effects of using alternative predictors, see Hearings, supra, at 156-57 (statement of Douglas Laycock on behalf of the American Association of University Professors). If Benston's high estimates were taken seriously, however, they would tend to show the egregiousness of existing discrimination. Benston claims that correcting this discrimination will transfer wealth from men to women, Benston, supra note 11, at 274-77, but this is true only in the sense that any nondiscrimination statute deprives some class of persons of benefits they have unjustly received at the expense of the now-protected class.

${ }^{104}$ Benston gives lip service to the legal notion that sex is a suspect classification, Benston, supra note 1, at 493 , but that idea has no apparent impact on his analysis. For example, he equates the unavoidable error in predicting mortality changes by sex with the unavoidable errors in predicting mortality changes at all. Id. at 527. But see supra notes 156-57 and accompanying text. 